\title{
OPTIMASI FORMULA STICK BALM MINYAK ATSIRI DAUN SEREH (Cymbopogon citratus)
}

\author{
I Komang Ary Werdhi Widnyana ${ }^{1}$, Windah Anugrah Subaidah ${ }^{1 *}$, Nisa Isneni Hanifa ${ }^{1}$ \\ ${ }^{1}$ Program Studi Farmasi, Fakultas Kedokteran, Universitas Mataram, Jalan Majapahit No. 62, Mataram, Kode Pos 83125 \\ *e-mail:windahanugrah@unram.ac.id
}

\begin{abstract}
ABSTRAK
Kandungan pada minyak atsiri daun sereh (Cymbopogon citratus) memiliki efek sebagai neurobehavioral, sehingga minyak atsiri daun sereh dapat bermanfaat sebagai aromaterapi. Untuk meningkatkan kenyamanan pengguna dan kemudahan dalam pengaplikasiannya, diperlukan inovasi baru sediaan aromaterapi berupa sediaan stick balm. Penelitian ini bertujuan untuk menentukan formula optimum serta sifat fisik sediaan stick balm minyak atsiri daun sereh dengan variasi zat tambahan cera alba dan lanolin. Delapan rancangan formula stick balm ditentukan menggunakan metode SLD (Simplex Lattice Design), dengan aplikasi Design Expert 11, dan dibuat menggunakan metode peleburan. Stick balm diuji sifat fisik meliputi uji pH, titik leleh, dan daya lekat. Respon uji sifat fisik diolah untuk memperoleh formula optimum. Sediaan optimum stick balm diuji sifat fisik, organoleptis, dan homogenitas. Hasil uji sifat fisik sediaan optimum diverifikasi dengan metode one sample t-test menggunakan aplikasi SPSS. Hasil optimasi formula diperoleh konsentrasi lanolin 5,310\% dan cera alba 11,690\%. Sediaan optimum stick balm berwarna kuning cerah, bau khas minyak sereh, konsistensi semi padat, bahan tercampur homogen, nilai $\mathrm{pH} 5,63 \pm 0,06$, titik leleh $44,5 \pm 0,5^{\circ} \mathrm{C}$, dan daya lekat $2,437 \pm 0,106$ detik, sehingga sediaan optimum stick balm memenuhi syarat fisik. Sifat fisik sediaan optimum tidak berbeda signifikan dengan prediksi pada aplikasi Design Expert 11.
\end{abstract}

Kata kunci: optimasi, sereh, stick balm, simplex lattice design.

\begin{abstract}
The content in lemongrass leaves essential oil (Cymbopogon citratus) has a neurobehavioral effect, so lemongrass leaves essential oil can be useful as aromatherapy. The stick balm form as an innovation of aromatherapy form is required to increase the user's comfort and ease of application of the product. The aim of this study is to determine the optimum formula and physical properties of lemongrass essential oil stick balm form with additive variations of cera alba and lanolin. Eight stick balm formula designs were determined by using SLD (Simplex Lattice Design), method with Design Expert 11 software, and made by using melting method. The stick balm forms were tested for the physical properties such as pH test, melting point test, and adhesion test. The response to the physical properties test was processed by using Design Expert 11 software to obtain optimal formula. The optimal form of stick balm was tested for physical, organoleptic, and homogeneity properties. The results of the physical properties test of optimal formula were verified by using one sample t-test method with SPSS software. The results of the optimization of the formula were 5,310\% of lanolin and $11,690 \%$ of cera alba. The stick balm forms were bright yellow in color, have a characteristic smell of lemongrass essential oil, semi-solid consistency, homogeneous mixed materials, $\mathrm{pH}$ level of 5,63 $\pm 0,06$, melting point of $44,5 \pm 0,5 \mathrm{oC}$, and adhesion tests of $2,437 \pm 0,106$ seconds, with the result that, the optimum formula of stick balm met requirements for the physical properties. The physical properties of the optimal formula are not significantly different from the predictions in the Design Expert 11 application.
\end{abstract}

Keywords: optimal, lemongrass, stick balm, simplex lattice design.

\section{PENDAHULUAN}

Tingkat stres yang tinggi akan berpengaruh pada masalah biologis, psikologis, dan sosial (Tucker et al., 2008). Stres dapat disebabkan oleh lingkungan atau individu itu sendiri sehingga dapat menyebabkan kecemasan, emosi, perasaan negatif seperti tekanan, rasa nyeri, kesedihan, dan gangguan jiwa/psikologis (Tse et al., 2007). Menurut hasil RISKESDAS (Riset Kesehatan Indonesia) kasus gangguan jiwa mengalami peningkatan menjadi 7,1\% pada tahun 2018 dari tahun 2013 sebesar $1,7 \%$. Gangguan depresi mulai terjadi sejak usia remaja (15 - 24 tahun) dengan prevalensi sebesar 6,2\%. Khususnya di Nusa Tenggara Barat prevalensi depresi pada penduduk umur $\geq 15$ tahun sebesar $8,8 \%$ (Kementerian Kesehatan RI, 2018).

Kondisi stres dapat diatasi dengan berbagai macam cara, salah satunya dengan cara alternatif yaitu penggunaan aromaterapi. Aromaterapi merupakan bentuk pengobatan komplementer dan alternatif dengan menggunakan minyak atsiri. Aromaterapi dapat memicu perubahan pada sistem limbik sehingga akan berpengaruh pada detak jantung, tekanan darah, pernapasan, dan pelepasan berbagai hormon sehingga menimbulkan perasaan tenang. Aromaterapi memberikan efek dalam mengurangi rasa sakit dan kecemasan, meningkatkan energi dan memori jangka pendek, serta relaksasi. Pengaplikasian aromaterapi dapat digunakan sebagai terapi inhalasi dan pijat, diffuser, dan kompres panas atau dingin (Gaware et al., 2013).

Minyak atsiri pada sereh (Cymbopogon citratus) merupakan salah satu komoditas di antara 12 minyak atsiri yang diekspor oleh Indonesia. Minyak atsiri yang dihasilkan pada bagian daun sereh memiliki nilai rendemen 10 kali lebih besar dibandingkan pada bagian batang (Zaituni et al., 2016). Kandungan minyak atsiri daun sereh ( $C$. citratus) dapat digunakan sebagai bahan 
Jurnal Penelitian Farmasi Indonesia 10(2), Desember 2021

ISSN : 2302-187X e-ISSN 2656-3614

baku parfum, antiseptik, kosmetik, dan bahan aromaterapi (Sulaswatty et al., 2019). Penelitian oleh Blanco et al. (2009) menunjukkan bahwa kandungan citral dan myrcene pada minyak atsiri daun sereh $(C$. citratus) mampu meningkatkan waktu tidur, memiliki efek sedatif, dan ansiolitik pada mencit. Pemilihan minyak atsiri daun sereh dengan konsentrasi sebesar $15 \%$ sudah dapat memberikan aroma khas yang tajam, sensasi hangat, dan perasaan menenangkan (Purba et al., 2020).

Sebagian besar masyarakat Indonesia memanfaatkan minyak atsiri terbatas dalam bentuk sediaan minyak topikal. Oleh karena itu, perlu inovasi sediaan lain seperti sediaan stick balm untuk meningkatkan kenyamanan pengguna serta kemudahan dalam pengaplikasiannya. Stick balm merupakan sediaan dengan basis seperti sediaan salep. Salep merupakan sediaan semi padat yang digunakan untuk pemakaian luar atau topikal pada bagian kulit atau selaput lendir. Perbedaan sediaan stick balm dengan salep yaitu berdasarkan tingkat konsistensinya, stick balm memiliki konsistensi lebih keras dibandingkan salep (Anief, 2013).

Pada formulasi salep diperlukan basis yang berfungsi sebagai zat pembawa yang bersifat inaktif serta memiliki bentuk cair atau padat yang akan membawa bahan aktif untuk diaplikasikan pada kulit. Idealnya suatu basis mudah dioleskan, mudah dibersihkan, dan tidak mengiritasi. Basis yang cocok untuk pengaplikasian aromaterapi pada kulit yaitu basis salep serap anhidrat karena kandungan lemak yang tinggi, kadar air yang sedikit, dan minyak atsiri akan mudah larut dalam lemak (Yanhendri, 2012).

Pemilihan zat tambahan sediaan stick balm pada basis serap anhidrat perlu diperhatikan, karena dapat mempengaruhi sifat fisik sediaan. Sifat fisik yang dipengaruhi yakni titik leleh, daya lekat, dan $\mathrm{pH}$. Bahan tambahan yang sering digunakan dalam basis serap anhidrat seperti cera alba dan lanolin. Cera alba berfungsi sebagai agen peningkat konsistensi dan lanolin berfungsi sebagai pelembut pada kulit (Rowe et al., 2006; Sandi \& Musfirah, 2018). Penelitian yang telah dilakukan Purba et al. (2020) tentang formulasi sediaan stick balm minyak atsiri sereh hanya melakukan variasi konsentrasi zat aktif $(15 \%, 20 \%$, dan $25 \%)$. Berdasarkan hal tersebut, maka tujuan penelitian ini adalah untuk menentukan formula optimum serta sifat fisik dengan variasi zat tambahan cera alba dan lanolin terhadap sediaan stick balm minyak atsiri daun sereh $(C$. citratus). Optimasi formula yang dilakukan menggunakan aplikasi Design Expert 11.

\section{METODE PENELITIAN}

\section{Alat dan Bahan}

Alat - alat yang digunakan pada penelitian ini antara lain timbangan (Ohaus, USA), alat gelas, mortar, stamper, sudip, hotplate (Labnet International, Inc., USA), pH meter (Ohaus, USA), stopwatch, kaca objek, beban $1 \mathrm{~kg}$, aplikasi Design Expert 11 dan SPSS, gelas arloji.

Bahan - bahan yang digunakan pada penelitian ini antara lain minyak atsiri daun sereh ( $C$. citratus) yang diperoleh dari hasil distilasi air di daerah Ampenan, Nusa Tenggara Barat, paraffin cair $(\text { Brataco })^{\circledR}$, cera alba $(\text { Brataco })^{\circledR}$, lanolin $(\text { Brataco })^{\circledR}$, isopropil miristat $(\text { Brataco })^{\circledR}$, vaselin alba $(\text { Brataco })^{\circledR}$, dan propil paraben $(\text { Brataco })^{\circledR}$.

\section{Penentuan Nilai Lower dan Upper Limit}

Nilai lower dan upper limit digunakan untuk menentukan formula yang akan dioptimasi berupa lanolin dan cera alba. Ditentukan nilai lower dan upper limit secara berturut - turut yaitu 3\% - 6\% pada lanolin dan $11 \%$ - 14\% pada cera alba. Parameter respon yang digunakan dalam menentukan sifat fisik yaitu nilai $\mathrm{pH}$, titik leleh, dan daya lekat. Formula dari hasil penetuan nilai lower dan upper limit terdapat pada Tabel 1.

\section{Formulasi Stick Balm Minyak Atsiri Daun Sereh}

Sediaan stick balm minyak atsiri daun sereh dibuat sesuai pada Tabel 1 menggunakan metode peleburan. Dilakukan penimbangan masing - masing bahan. Bahan diletakkan di atas penangas air dan dileburkan dengan suhu $85^{\circ} \mathrm{C}$. Proses peleburan dimulai dengan memasukkan bahan cera alba, propil paraben yang telah digerus, lanolin, vaselin alba, paraffin cair, dan isopropil miristat. Setelah semua bahan lebur, ketika campuran dalam kondisi tidak terlalu panas, dilakukan penambahan minyak atsiri daun sereh. Dilakukan pengadukan hingga homogen dan dimasukan ke dalam wadah stick balm. Selanjutnya didiamkan dengan suhu ruang dan diletakkan di dalam pendingin selama 24 jam hingga sediaan tercetak dalam wadah (Purba et al., 2020). Kemudian dilakukan uji sifat fisik sediaan meliputi uji pH, titik leleh, dan daya lekat.

\section{Evaluasi Sifat Fisik Sediaan}

\section{a. Uji pH}

Pengujian $\mathrm{pH}$ menggunakan alat $\mathrm{pH}$ meter dengan meleburkan bahan terlebih dahulu dengan suhu $\pm 45^{\circ} \mathrm{C}$. Kemudian pengujian dengan melakukan kalibrasi alat $\mathrm{pH}$ meter terlebih dahulu. Setelah dilakukan pengujian akan muncul nilai $\mathrm{pH}$. Angka yang muncul pada keadaan konstan merupakan nilai $\mathrm{pH}$ dari sediaan. Nilai pH yang baik pada sediaan stick balm adalah 4,5-6,5 atau sesuai dengan nilai $\mathrm{pH}$ kulit pada manusia (Novita et al., 2017).

\section{b. Uji Titik Leleh}

Uji titik leleh dilakukan dengan cara ditimbang sediaan sebanyak $1 \mathrm{~g}$. Kemudian sediaan stick balm diletakkan di atas waterbath hingga meleleh. Suhu stick balm diukur menggunakan termometer (Warnida et al., 2016). Syarat titik leleh sediaan lipstik yang baik menurut SNI 16-4769-1998 yang baik yaitu pada suhu $50-70^{\circ} \mathrm{C}$ (Maysarah et al., 2020). 
Jurnal Penelitian Farmasi Indonesia 10(2), Desember 2021

ISSN : 2302-187X e-ISSN 2656-3614

Tabel 1. Formula stick balm variasi konsentrasi cera alba dan lanolin (Butler, 2000)

\begin{tabular}{|c|c|c|c|c|c|c|c|c|c|}
\hline \multirow{2}{*}{ Bahan (b/b) } & \multirow{2}{*}{ Fungsi } & \multicolumn{8}{|c|}{ Formula (\%) } \\
\hline & & F1 & F2 & F3 & F4 & F5 & F6 & F7 & F8 \\
\hline Minyak atsiri daun sereh & Zat aktif & 15 & 15 & 15 & 15 & 15 & 15 & 15 & 15 \\
\hline Paraffin cair & Emolien & 2,4 & 2,4 & 2,4 & 2,4 & 2,4 & 2,4 & 2,4 & 2,4 \\
\hline Lanolin* & Pelembut & 6 & 3 & 4,5 & 5,25 & 3,75 & 6 & 3 & 4,5 \\
\hline Cera alba* & Peningkat konsistensi & 11 & 14 & 12,5 & 11,75 & 13,25 & 11 & 14 & 12,5 \\
\hline Isopropil miristat & Peningkat penetrasi & 6,4 & 6,4 & 6,4 & 6,4 & 6,4 & 6,4 & 6,4 & 6,4 \\
\hline Propil paraben & Pengawet & 0,1 & 0,1 & 0,1 & 0,1 & 0,1 & 0,1 & 0,1 & 0,1 \\
\hline Vaselin alba ad & Basis & 100 & 100 & 100 & 100 & 100 & 100 & 100 & 100 \\
\hline
\end{tabular}

Keterangan:

* = bahan tambahan yang dioptimasi

\section{c. Uji Daya Lekat}

Sebanyak 0,5 g sediaan stick balm minyak atsiri daun sereh diletakkan di atas kaca objek I yang telah ditentukan luasnya. Kemudian diletakkan di atasnya dengan kaca objek II. Kemudian diberikan beban $1 \mathrm{~kg}$ dalam waktu 5 menit. Lalu beban diangkat dan dua objek gelas yang berlekatan diletakkan pada alat uji. Beban yang digunakan dalam pengujian yaitu $80 \mathrm{~g}$. Kemudian dicatat waktu hingga kedua kaca objek terpisah (Azkiya et al., 2017). Adapun syarat uji daya lekat yang baik untuk sediaan topikal yaitu lebih dari 1 detik (Irianto et al., 2020).

\section{Pembuatan Sediaan Optimum Stick Balm}

Pemilihan formula optimum stick balm berdasarkan hasil evaluasi sifat fisik sediaan dan dibuat sediaan stick balm dengan langkah yang sama seperti di atas.

\section{Evaluasi Sediaan Optimum Stick Balm}

Pada evaluasi sediaan optimum stick balm dilakukan uji sifat fisik berupa uji titik leleh, daya lekat, dan $\mathrm{pH}$, dan ditambah dengan uji organoleptis meliputi warna, bau, dan konsistensi sediaan optimum yang diamati secara visual serta uji homogenitas.

\section{a. Uji Organoleptis}

Uji organoleptis meliputi uji warna, bau, dan konsistensi yang diamati secara visual. Syarat stick balm yang baik yaitu memiliki bentuk setengah padat, warna harus sesuai dengan spesifikasi pada saat pembuatan awal stick balm dan tidak memiliki bau tengik (Sandi \& Musfirah, 2018).

\section{b. Uji Homogenitas}

Sebanyak 0,5 g sediaan stick balm minyak atsiri daun sereh diletakkan di atas kaca objek kemudian diratakan dan diamati secara visual. Stick balm yang homogen ditandai dengan tidak terdapat gumpalan pada hasil di atas kaca objek (Naibaho et al., 2013).

\section{Verifikasi Sediaan Optimum Stick Balm}

Hasil evaluasi formula optimum stick balm dilakukan verifikasi formula dengan membandingkan respon ( $\mathrm{pH}$, daya titik leleh, dan daya lekat) yang diperoleh dari hasil prediksi aplikasi Design Expert 11 dan hasil percobaan.

\section{Analisis Data}

Sediaan stick balm minyak atsiri daun sereh dioptimasi menggunakan metode simplex lattice design (SLD) menggunakan aplikasi Design Expert 11. Parameter respon yang diamati diantaranya terdapat $\mathrm{pH}$, titik leleh, dan daya lekat. Persamaan model matematika tersebut kemudian dibuat suatu profil yang menggambarkan sifat fisik dengan variasi lanolin dan cera alba. Kemudian hasil tersebut digunakan untuk menentukan formula optimum (Paramita, 2008). Setelah diperoleh formula optimum dilakukan verifikasi formula menggunakan analisis data statistik melalui uji one sample t-test menggunakan aplikasi SPSS.

\section{HASIL DAN PEMBAHASAN}

\section{Optimasi Formula Stick Balm Minyak Atsiri Daun Sereh}

Penentuan formula optimum dilakukan menggunakan aplikasi Design Expert 11 dengan metode simplex lattice design. Alasan penggunaan bahan tambahan dalam formulasi sediaan stick balm berdasarkan adaptasi formula dari buku Pouchers, Perfumes, Cosmetics, and Soaps (edisi ke-10) dan dilakukan tahap performulasi terlebih dahulu sebelum menentukan formula untuk dilakukan optimasi. Pengoptimasian bahan tambahan cera alba dan lanolin, karena berdasarkan fungsi dan sifat fisik dari bahan tersebut memiliki berbeda. Cera alba berfungsi sebagai peningkat konsistensi dan memiliki sifat fisik padat seperti lilin, sedangkan lanolin berfungsi sebagai pelembut memiliki sifat fisik semi padat.

Penentuan formula optimum berdasarkan parameter respon nilai $\mathrm{pH}$, titik leleh, dan daya lekat. Penentuan parameter $\mathrm{pH}$ agar ketika dilakukan pengaplikasian pada kulit tidak menimbulkan iritasi dan sesuai pada $\mathrm{pH}$ kulit. Penentuan parameter titik leleh yaitu ketika dilakukan penyimpanan, sediaan tetap memiliki bentuk utuh dan tidak meleleh pada suhu ruang. Penentuan parameter daya lekat agar diaplikasikan pada kulit, sediaan stick balm mampu menempel memberikan efikasi dan sesuai dengan syarat daya lekat sediaan topikal. Sehingga, berdasarkan ketiga parameter tersebut diharapkan memiliki syarat sediaan stick balm yang baik. Nilai respon untuk masing - 
Jurnal Penelitian Farmasi Indonesia 10(2), Desember 2021

ISSN : 2302-187X e-ISSN 2656-3614

Tabel 2. Nilai respon dari masing - masing run dalam optimasi formula

\begin{tabular}{cccccc}
\hline \multirow{2}{*}{$\boldsymbol{R} \boldsymbol{N}$} & \multicolumn{2}{c}{ Komponen (\%) } & \multicolumn{2}{c}{ Respon } \\
\cline { 2 - 5 } & A: Lanolin & $\mathbf{~ B : ~ C e r a ~ a l b a ~}$ & $\mathbf{p H}$ & Titik Leleh $\left({ }^{\mathbf{0}} \mathbf{C}\right)$ & Daya Lekat (Detik) \\
\hline 1 & 5,25 & 11,75 & $5,69 \pm 0,04$ & $45,0 \pm 0,5$ & $2,360 \pm 0,017$ \\
2 & 3 & 14 & $5,88 \pm 0,02$ & $45,7 \pm 0,6$ & $2,083 \pm 0,061$ \\
3 & 3 & 14 & $5,84 \pm 0,03$ & $45,5 \pm 0,9$ & $2,063 \pm 0,075$ \\
4 & 4,5 & 12,5 & $5,30 \pm 0,06$ & $44,0 \pm 1,0$ & $2,250 \pm 0,030$ \\
5 & 6 & 11 & $5,52 \pm 0,14$ & $43,7 \pm 1,5$ & $1,727 \pm 0,055$ \\
6 & 4,5 & 12,5 & $5,44 \pm 0,06$ & $43,3 \pm 1,5$ & $2,090 \pm 0,040$ \\
7 & 6 & 11 & $5,68 \pm 0,02$ & $43,3 \pm 1,2$ & $1,783 \pm 0,040$ \\
8 & 3,75 & 13,25 & $5,33 \pm 0,10$ & $44,0 \pm 0,9$ & $1,753 \pm 0,064$ \\
\hline
\end{tabular}

masing run formula dapat dilihat pada Tabel 2. Setelah diperoleh nilai respon dilakukan analisis ANOVA untuk masing - masing run pada aplikasi Design Expert 11 yang disajikan pada Tabel 3 .

Setiap nilai parameter respon yang diperoleh dianalisis dengan ANOVA yang ada pada aplikasi Design Expert 11 untuk mengetahui signifikansi respon dan mengetahui model yang disarankan pada aplikasi. Hasil analisis yang baik dan dapat diterima memiliki beberapa kriteria diantaranya yaitu model linear mixture dengan nilai $\mathrm{p}$-value $<0,05$ yang menandakan bahwa nilai tersebut bersifat signifikan. Selanjutnya nilai lack of fit dengan nilai $\mathrm{p}$-value $>0,05$ yang menandakan nilai tersebut bersifat tidak signifikan. Nilai lack of fit yang tidak signifikan menunjukkan model yang diinginkan sesuai dan memiliki noise (pengganggu) yang kecil. Nilai $R$-square yang mendekati 1 menandakan bahwa model tersebut disarankan. Pada nilai adeq.precision yang lebih besar dari 4 menunjukkan bahwa model tersebut dapat diterima. Pada penelitian ini, nilai ketiga respon tersebut telah memenuhi syarat hasil analisis yang baik.

Tabel 3. Data hasil analisis ANOVA masing - masing respon dengan aplikasi Design Expert 11

\begin{tabular}{lccc}
\hline & \multicolumn{3}{c}{ Respon } \\
\cline { 2 - 4 } \multicolumn{1}{c}{ Parameter } & $\mathbf{p H}$ & $\begin{array}{c}\text { Titik } \\
\text { Leleh } \\
\left({ }^{\circ} \mathbf{C}\right)\end{array}$ & $\begin{array}{c}\text { Daya } \\
\text { Lekat } \\
\text { (Detik) }\end{array}$ \\
\hline Model: linier mixture & 0,0118 & 0,0302 & 0,0037 \\
Residual: Lack offit & 0,5910 & 0,1309 & 0,4843 \\
R-square & 0,9195 & 0,8701 & 0,9550 \\
Adeq.precision & 9,5843 & 6,4994 & 13,6270 \\
\hline
\end{tabular}

$$
\begin{aligned}
\text { a. } & \text { Nilai pH } \\
\mathrm{Y}= & 5,61(\mathrm{~A})+5,86(\mathrm{~B})-1,36(\mathrm{AB})+ \\
& 2,59(\mathrm{AB}(\mathrm{A}-\mathrm{B})) \\
\text { Keterangan } & \\
\mathrm{Y}= & \text { Respon nilai } \mathrm{pH} \\
\mathrm{A}= & \text { Konsentrasi lanolin } \\
\mathrm{B}= & \text { Konsentrasi cera alba }
\end{aligned}
$$

Hasil analisis data pada nilai $\mathrm{pH}$, diperoleh persamaan model cubic dan persamaan Simplex Lattice Design yang menggambarkan nilai respon dari $\mathrm{pH}$ seperti yang ditunjukkan pada persamaan (1).
Berdasarkan persamaan yang menggambarkan nilai respon $\mathrm{pH}$, masing - masing komponen lanolin $(+5,61)$ dan cera alba $(+5,86)$ menunjukkan koefisien positif, sehingga penambahan kedua bahan ini mampu meningkatkan nilai $\mathrm{pH}$. Tetapi pada interaksi antara dua komponen yaitu lanolin dan cera alba menunjukkan respon negatif $(-1,36)$, sehingga akan berpengaruh terhadap penurunan nilai $\mathrm{pH}$ pada sediaan. Pada interaksi yang lebih kompleks antara lanolin dan cera alba dengan melibatkan interaksi selisih antara kedua bahan menghasilkan respon positif $(+2,59)$.

Sediaan stick balm idealnya memiliki nilai $\mathrm{pH}$ sesuai dengan $\mathrm{pH}$ kulit yaitu 4,5 - 6,5. Hal ini untuk mencegah iritasi pada kulit ketika dilakukan pengaplikasian. Nilai suatu $\mathrm{pH}$ sediaan dapat dipengaruhi salah satunya berdasarkan struktur dari zat tambahan. Cera alba merupakan lilin alami yang diproduksi dari sarang lebah dari lebah madu. Susunan struktur cera alba sendiri mengandung ester asam lemak dan berbagai alkohol rantai panjang. Struktur dari asam lemak mengandung gugus fungsi asam karboksilat (-COOH) (Sisco Research Laboratories Ltd., 2021a). Selain itu juga dilakukan penelitian oleh Anjari et al. (2015) dengan menguji basis cera alba pada lip gloss bahwa sediaan tersebut memiliki nilai $\mathrm{pH}$ 5,57. Sedangkan pada lanolin atau wool wax tersusun atas struktur ester dan keton memiliki nilai $\mathrm{pH}(10 \% \mathrm{Aq})$ 4 - 7 dan dapat dikategorikan sebagai asam (Sisco Research Laboratories Ltd., 2021b). Oleh karena itu, jika dikombinasikan kedua bahan tersebut pada konsentrasi yang optimal, akan menghasilkan nilai $\mathrm{pH}$ yang semakin asam. Hal ini dapat dilihat berdasarkan pengujian pada Run ke-4 memiliki nilai pH 5,30 (Tabel 2).

\section{b. Titik Leleh}

$$
\begin{aligned}
\mathrm{Y}= & 43,55(\mathrm{~A})+45,65(\mathrm{~B})-2,62(\mathrm{AB})+ \\
& 10,93(\mathrm{AB}(\mathrm{A}-\mathrm{B}))
\end{aligned}
$$

Keterangan:

$\mathrm{Y} \quad=$ Respon titik leleh

A $=$ Konsentrasi lanolin

$\mathrm{B}=$ Konsentrasi cera alba

Hasil analisis data titik leleh, diperoleh model cubic dan persamaan Simplex Lattice Design yang menggambarkan nilai respon dari titik leleh seperti yang ditunjukkan pada persamaan (2). Berdasarkan 
Jurnal Penelitian Farmasi Indonesia 10(2), Desember 2021

ISSN : 2302-187X e-ISSN 2656-3614

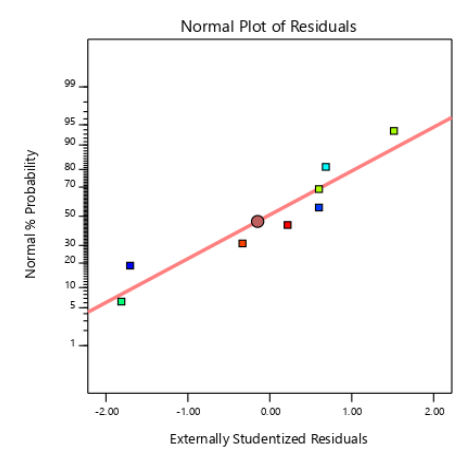

(a)

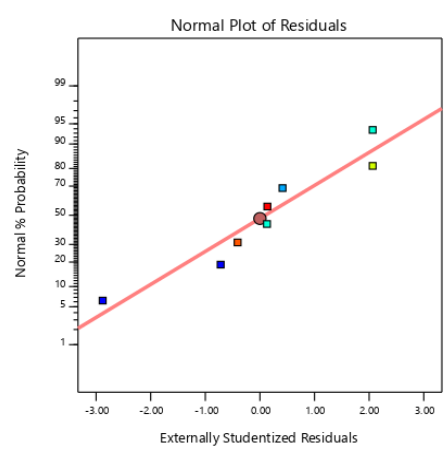

(b)

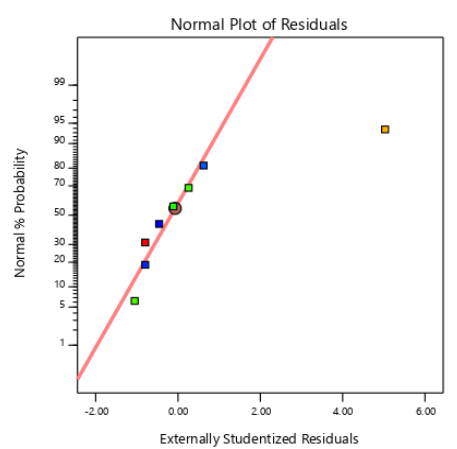

(c)

Gambar 1. Normal plot of residual masing-masing respon uji (Keterangan = (a) pH; (b) Titik leleh; (c) Daya lekat)

persamaan yang menggambarkan nilai respon titik leleh, masing - masing komponen lanolin $(+43,55)$ dan cera alba $(+45,65)$ menunjukkan koefisien positif, sehingga pada masing - masing komponen mampu meningkatkan titik leleh. Tetapi yang paling mempengaruhi yaitu pada konsentrasi cera alba karena nilainya lebih besar dibandingkan lanolin. Sedangkan pada interaksi antara dua komponen yaitu lanolin dan cera alba menunjukkan respon negatif $(-2,62)$, sehingga akan berpengaruh terhadap penurunan titik leleh pada sediaan. Pada interaksi yang lebih kompleks antara lanolin dan cera alba dengan melibatkan interaksi selisih antara kedua bahan menghasilkan respon positif $(+10,93)$.

Nilai titik leleh pada sediaan stick balm dapat dipengaruhi oleh titik leleh pada masing - masing zat tambahan yang digunakan. Pada penelitian ini, zat tambahan cera alba yang berfungsi sebagai peningkat konsistensi memiliki titik leleh sebesar $61-65^{\circ} \mathrm{C}$ (Sisco Research Laboratories Ltd., 2021a), sedangkan pada lanolin berfungsi sebagai sebagai agen pengemulsi, emolien, dan pelembut pada kulit memiliki titik leleh sebesar $34-44^{\circ} \mathrm{C}$ (Sisco Research Laboratories Ltd., 2021b). Penambahan cera alba dengan titik leleh yang lebih tinggi menunjukkan koefisien positif yang terdapat pada persamaan (2), sehingga penambahan konsentrasi cera alba dapat meningkatkan nilai titik leleh sediaan stick balm. Hasil analisis data pada daya lekat, diperoleh model cubic dan persamaan Simplex Lattice Design yang menggambarkan nilai respon dari daya lekat seperti yang ditunjukkan pada persamaan (3). Berdasarkan persamaan yang menggambarkan nilai respon daya lekat, masing - masing komponen lanolin $(+1,75)$ dan cera alba $(+2,07)$ menunjukkan koefisien positif, sehingga pada masing - masing komponen mampu meningkatkan daya lekat. Tetapi yang paling mempengaruhi yaitu pada konsentrasi cera alba karena nilainya lebih besar dibandingkan lanolin. Pada interaksi antara dua komponen yaitu lanolin dan cera alba menunjukkan respon positif $(+0,9464)$, sehingga kombinasi lanolin dan cera alba mampu meningkatkan daya lekat. Pada interaksi yang lebih kompleks antara lanolin dan cera alba dengan melibatkan interaksi selisih antara kedua bahan juga menghasilkan respon positif $(+4,09)$.
Daya lekat suatu sediaan dapat dipengaruhi oleh zat tambahan yang digunakan. Pada penelitian ini zat tambahan yang digunakan cera alba memiliki bentuk lempeng padatan lilin, sedangkan lanolin memiliki bentuk semi solid. Menurut Arisanti et al. (2016) nilai daya lekat suatu sediaan dapat dipengaruhi oleh penambahan konsentrasi cera alba. Tetapi jika penambahan cera alba terlalu banyak dapat membuat sediaan menjadi kaku dan sulit untuk dilakukan pengolesan pada kulit. Pada penelitian yang dilakukan oleh Fitriana et al. (2012), penambahan jumlah lanolin memberikan efek daya lekat yang semakin meningkat juga. Ketika konsentrasi lanolin yang ditambahkan terlalu banyak, maka akan membuat sediaan memiliki bentuk semi padat dan tidak memiliki konsistensi sediaan stick balm. Kombinasi konsentrasi yang optimal pada lanolin dan cera alba dapat memberikan daya lekat yang semakin lama dan memberikan konsistensi sediaan yang baik. Hal ini dapat terlihat pada hasil pengujian dengan konsentrasi yang optimal antara kombinasi cera alba dan lanolin memberikan efek daya lekat serta memiliki konsistensi sediaan stick balm yang maksimal. c. Daya Lekat

$$
\begin{aligned}
& \mathrm{Y}= 1,75(\mathrm{~A})+2,07(\mathrm{~B})+0,9464(\mathrm{~A})(\mathrm{B})+ \\
& 4,09(\mathrm{AB}(\mathrm{A}-\mathrm{B})) \\
& \text { Keterangan: } \\
& \mathrm{Y}=\text { Respon daya lekat } \\
& \mathrm{A}=\text { Konsentrasi lanolin } \\
& \mathrm{B}=\text { Konsentrasi cera alba }
\end{aligned}
$$

\section{Kurva Normal Plot of Residual}

Kurva normal plot of residual diperoleh dari aplikasi Design Expert 11 untuk masing - masing respon yang disajikan pada Gambar 1. Kurva normal plot of residual dari masing - masing respon menggambarkan persebaran data terhadap suatu persamaan garis linier (persamaan formula optimum), terlihat bahwa data menyebar di sekitar garis diagonal dan mengikuti arah garis diagonal. Hal tersebut, menandakan data terdistribusi secara normal, sehingga dapat dilanjutkan uji ANOVA pada aplikasi Design Expert 11 (Ittiqo \& Wahid, 2019). Kemudian data yang dihasilkan dilakukan analisis ANOVA dan didapatkan juga data optimasi seperti yang terdapat pada Tabel 5 . 
Jurnal Penelitian Farmasi Indonesia 10(2), Desember 2021

ISSN : 2302-187X

e-ISSN 2656-3614

Tabel 4. Komposisi formula optimum dan respon hasil prediksi aplikasi Design Expert 11

\begin{tabular}{cccccc}
\hline \multicolumn{2}{c}{ Komposisi (\%) } & Respon & \multirow{2}{*}{ Desirability } \\
\cline { 1 - 5 } Lanolin (A) & Cera Alba (B) & Nilai pH & Titik Leleh $\left({ }^{\circ} \mathbf{C}\right)$ & Daya Lekat (detik) & \\
\hline 5,310 & 11,690 & 5,670 & 44,613 & 2,383 & 0,923 \\
\hline
\end{tabular}

Tabel 5. Data optimasi sediaan stick balm menggunakan aplikasi Design Expert 11

\begin{tabular}{lcccc}
\hline \multicolumn{1}{c}{ Name } & Goal & LL & UL & Importance \\
\hline Lanolin (A) & IR & 3 & 6 & 3 \\
Cera Alba (B) & IR & 11 & 14 & 3 \\
Nilai pH & IR & 4,5 & 6,5 & 3 \\
Titik Leleh & IR & 40 & 50 & 3 \\
Daya Lekat & IR & 1 & 4 & 3 \\
\hline
\end{tabular}

Keterangan:

$\mathrm{LL}=$ lower limit

$\mathrm{UL}=$ upper limit

$\mathrm{IR}=$ in range

Berdasarkan Tabel 5, nilai importance yang digunakan pada penelitian ini yaitu 3. Nilai importance berperan sebagai derajat kepentingan, semakin tinggi nilai importance yang digunakan maka semakin tinggi derajat kepentingan respon tersebut. Semakin tinggi nilai derajat kepentingan respon, maka semakin berpengaruh dalam optimasi suatu sediaan dan pemenuhan kriteria yang diharapkan dari formula yang dihasilkan.

Setelah diperoleh data optimasi dan persamaan untuk masing - masing parameter kemudian diperoleh komposisi formula optimum hasil prediksi aplikasi Design Expert 11 yang disajikan pada Tabel 4. Kemudian dari data prediksi tersebut dihasilkan formula optimum dengan nilai desirability 0,923. Nilai desirability yang mendekati 1 menunjukkan formula yang diharapkan, artinya semakin tinggi kesesuaian formula yang diperoleh untuk mencapai formula yang optimum (Ittiqo \& Wahid, 2019). Sebaliknya jika nilai desirability mendekati 0 , menunjukkan formula yang tidak diharapkan (Gumbara et al., 2015).

Formulasi Sediaan Optimum Stick Balm Minyak Atsiri Daun Sereh

Tabel 6. Formula optimum dari aplikasi Design Expert 11

\begin{tabular}{lc}
\hline \multicolumn{1}{c}{ Bahan (b/b) } & Jumlah (\%) \\
\hline Minyak atsiri daun sereh & 15 \\
Paraffin cair & 2,4 \\
Lanolin & 5,310 \\
Cera alba & 11,690 \\
Isopropil miristat & 6,4 \\
Propil paraben & 0,1 \\
Vaselin alba ad & 100 \\
\hline
\end{tabular}

Komposisi formula optimum yang telah diperoleh dari hasil prediksi aplikasi Design Expert 11 kemudian dibuat sediaan stick balm dengan formula optimum yang telah disajikan pada Tabel 6. Proses pembuatan sediaan optimum dengan meleburkan bahan meliputi cera alba, propil paraben, lanolin, vaselin alba, paraffin cair, dan isopropil miristat hingga tercampur secara homogen. Ketika basis sediaan dalam kondisi suhu tidak terlalu panas, lalu ditambahkan minyak atsiri daun sereh sebanyak $15 \%$. Penambahan minyak atsiri daun sereh pada kondisi suhu tersebut, bertujuan untuk mencegah minyak atsiri menguap. Hal ini, disebabkan sifat minyak atsiri secara umum memiliki titik uap yang rendah dan kurang stabil terhadap suhu tinggi (Astuti et al., 2010).

Penelitian Purba et al. (2020) telah memformulasi minyak atsiri sereh dengan konsentrasi 15\%, 20\%, dan $25 \%$. Semakin tinggi konsentrasi minyak atsiri, maka sediaan semakin berminyak dan konsistensi stick balm menjadi lunak. Sehingga, alasan penambahan minyak atsiri daun sereh dengan konsentrasi sebesar 15\%, karena pada konsentrasi tersebut telah terdapat aroma khas sereh dan memberikan konsistensi sediaan stick balm yang baik dan tidak terlalu berminyak. Penelitian yang dilakukan Blanco et al. (2009), pengujian minyak atsiri daun sereh memberikan pengaruh terhadap lama waktu tidur pada mencit. Kandungan yang terdapat pada minyak atsiri bekerja sebagai penginduksi enzim, mempengaruhi penurunan aktivitas sistem saraf pusat, sehingga minyak atsiri daun sereh dapat mempengaruhi aktivitas sedatif dan ansiolitik.

\section{Evaluasi Sediaan Optimum Stick Balm Minyak} Atsiri Daun Sereh

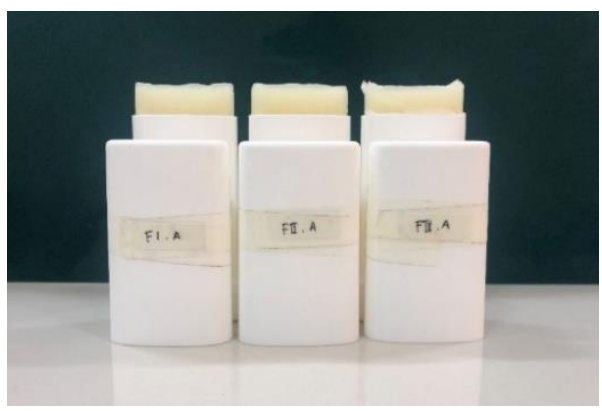

Gambar 2. Sediaan optimum stick balm minyak atsiri daun sereh

Evaluasi sifat fisik sediaan stick balm minyak atsiri daun sereh meliputi uji organoleptis, homogenitas, $\mathrm{pH}$, titik leleh, dan daya lekat. Hasil sediaan optimum stick balm dapat dilihat pada Gambar 2. Uji pertama yaitu uji organoleptis, pengujian ini dilakukan secara kualitatif dengan mengamati sediaan optimum pada stick balm minyak atsiri daun sereh. Pengamatan yang dilakukan pada uji organoleptis meliputi warna, bau, dan konsistensi sediaan stick balm minyak atsiri daun sereh. Data organoleptis sediaan optimum stick balm pada Tabel 7 telah sesuai dengan penelitian yang dilakukan oleh Purba et al. (2020). 
Jurnal Penelitian Farmasi Indonesia 10(2), Desember 2021

ISSN : 2302-187X e-ISSN 2656-3614

Tabel 7. Hasil uji organoleptis dan evaluasi sifat fisik sediaan optimum stick balm

\begin{tabular}{cc}
\hline Parameter & Hasil \\
\hline Warna & Kuning cerah \\
Bau & Bau khas daun sereh \\
Konsistensi & Semi padat \\
Homogenitas & Homogen \\
pH & $5,63 \pm 0,06$ \\
Titik leleh & $44,5 \pm 0,5^{\circ} \mathrm{C}$ \\
Daya lekat & $2,437 \pm 0,106$ detik \\
\hline
\end{tabular}

Tabel 8. Hasil analisis nilai respon prediksi dan percobaan

\begin{tabular}{lcccc}
\hline \multicolumn{1}{c}{ Respon } & Prediksi & Percobaan & Signifikansi 2-tailed & Kesimpulan \\
\hline $\mathrm{pH}$ & 5,67 & $5,63 \pm 0,06$ & 0,373 & Tidak berbeda \\
Titik leleh $\left({ }^{\circ} \mathrm{C}\right)$ & 44,613 & $44,5 \pm 0,5$ & 0,732 & Tidak berbeda \\
Daya lekat & 2,383 & $2,437 \pm 0,106$ & 0,476 & Tidak berbeda \\
\hline
\end{tabular}

Evaluasi selanjutnya yaitu dilakukan uji homogenitas pada sediaan stick balm minyak atsiri daun sereh. Uji homogenitas untuk mengetahui bahwa sediaan yang telah dibuat telah tercampur homogen atau tidak. Pengujian ini ditandai dengan ada atau tidaknya butiran kasar atau gumpalan pada pengujian (Athaillah \& Lianda, 2021). Hasil pengujian berupa data kualitatif dengan melihat sediaan telah tercampur secara homogen. Data hasil uji homogenitas dapat dilihat pada Tabel 7. Berdasarkan hasil uji, sediaan formula optimum telah tercampur secara homogen dan tidak terdapat butiran kasar atau gumpalan. Faktor yang mempengaruhi homogenitas suatu sediaan yaitu pada proses pencampuran bahan (Rachmawati et al., 2018). Pada penelitian ini proses pencampuran dilakukan dengan cara melelehkan semua bahan pada suhu tertentu, sehingga proses ini menentukan sediaan stick balm homogen atau tidak.

Setelah dilakukan pengujian dengan hasil berupa data kualitatif, kemudian dilakukan uji sifat fisik pada sediaan optimum stick balm meliputi uji pH, titik leleh, dan daya lekat. Hasil dari uji sifat fisik tertera pada Tabel 7. Pengujian nilai $\mathrm{pH}$ sediaan dilakukan dengan menggunakan alat $\mathrm{pH}$ meter. Tujuan dilakukan pengujian ini untuk mengetahui sediaan stick balm sudah memenuhi syarat $\mathrm{pH}$ untuk sediaan topikal yaitu 4,5 - 6,5 sesuai dengan $\mathrm{pH}$ kulit normal, sehingga sediaan stick balm ketika dioleskan pada permukaan kulit tidak menimbulkan iritasi jika pH terlalu asam atau terlalu basa (Novita et al., 2017). Berdasarkan pengujian yang telah dilakukan pada ketiga replikasi formula diperoleh nilai $\mathrm{pH}$ rata - rata sediaan optimum stick

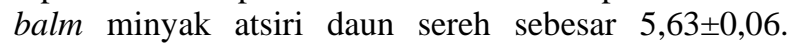
Berdasarkan hasil tersebut, bahwa sediaan stick balm sudah memenuhi syarat $\mathrm{pH}$ sediaan topikal dan aman untuk digunakan.

Pada penelitian ini yang mempengaruhi nilai $\mathrm{pH}$ sediaan adalah penambahan cera alba dan lanolin. Penambahan kombinasi dari zat tambahan membuat nilai pH menjadi lebih kecil (semakin asam). Selain itu, berdasarkan penelitian oleh (Purba et al., 2020), penambahan konsentrasi minyak atsiri daun sereh dapat membuat nilai $\mathrm{pH}$ menjadi lebih besar (semakin basa).

Evaluasi selanjutnya yakni uji titik leleh sediaan. Tujuan dilakukannya uji titik leleh sediaan untuk menentukan suhu yang optimal pada wadah atau sediaan ketika dilakukan penyimpanan pada suhu ruang, sehingga hal ini akan mencegah melelehnya sediaan pada suhu ruang. Kemudian, untuk membantu membuat sediaan menjadi aman ketika dilakukan proses packaging dan pengangkutan.

Hasil penelitian yang telah dilakukan diperoleh nilai uji titik leleh sediaan formula optimum stick balm sebesar $44,5 \pm 0,5^{\circ} \mathrm{C}$, selain itu saat dilakukan penyimpanan pada suhu ruang, konsistensi sediaan formula optimum stick balm masih dalam keadaan baik. Menurut SNI 16-4769-1998 terkait titik leleh yang baik pada lipstik yaitu suhu $50-70^{\circ} \mathrm{C}$. Sediaan stick balm sendiri, belum ada ketentuan standar terhadap titik leleh. Penelitian oleh (Maysarah et al., 2020), yang mempengaruhi titik leleh yaitu konsentrasi dari cera alba. Titik leleh sediaan stick balm terlalu tinggi akan mempengaruhi konsistensi sediaan menjadi semakin keras, sehingga proses pengaplikasian pada kulit akan sulit. Idealnya titik leleh sediaan stick balm, ketika dilakukan penyimpanan pada suhu ruang sediaan tidak meleleh dan konsistensinya masih sama ketika awal sediaan stick balm dibuka.

Evaluasi selanjutnya yaitu dilakukan pengujian daya lekat pada sediaan stick balm minyak atsiri daun sereh. Daya lekat bertujuan untuk mengetahui seberapa lama waktu melekatnya sediaan pada permukaan kulit, sehingga sediaan topikal mampu memberikan efikasi yang maksimal (Rohmani \& Kuncoro, 2019). Hasil uji daya lekat pada sediaan optimum stick balm bernilai $2,437 \pm 0,106$ detik. Syarat sediaan topikal memiliki daya lekat, melekat lebih dari 1 detik dan sediaan stick balm yang baik, ketika dilakukan pengolesan mampu menempel pada kulit (Athaillah \& Lianda, 2021; Irianto et al., 2020). Berdasarkan syarat tersebut, bahwa sediaan optimum stick balm telah memenuhi syarat sediaan topikal dan sediaan stick balm yang baik. Daya lekat 
Jurnal Penelitian Farmasi Indonesia 10(2), Desember 2021

ISSN : 2302-187X

e-ISSN 2656-3614

suatu sediaan dapat dipengaruhi oleh penambahan konsentrasi cera alba dan lanolin (Arisanti et al., 2016; Fitriana et al., 2012).

\section{Verifikasi Formula Optimum Sediaan Stick Balm Minyak Atsiri Daun Sereh}

Verifikasi formula optimum dilakukan dari ketiga uji diantaranya $\mathrm{pH}$, titik leleh, dan daya lekat. Tujuan dilakukannya verifikasi formula optimum yaitu untuk mengetahui adanya perbedaan secara signifikan atau tidak antara respon prediksi pada aplikasi Design Expert 11 dengan percobaan. Analisis perbedaan ini menggunakan metode analisis statistik One Sample $t$ test. Berdasarkan data pada Tabel 8 bahwa diperoleh nilai respon $\mathrm{pH}$, titik leleh, dan daya lekat dari prediksi aplikasi Design Expert 11 menunjukkan hasil yang tidak berbeda signifikan dengan nilai respon pada percobaan. Hal ini ditunjukkan dengan adanya nilai $\mathrm{p}$ (signifikansi 2-tailed) $>0,05$. Berdasarkan penelitian yang telah dilakukan, sediaan optimum stick balm minyak atsiri daun sereh telah memenuhi syarat sediaan stick balm.

\section{KESIMPULAN}

Berdasarkan penelitian yang telah dilakukan dapat disimpulkan formula optimum sediaan stick balm minyak atsiri daun sereh diperoleh pada proporsi cera alba sebesar $11,690 \%$ dan lanolin sebesar 5,310\%. Sifat fisik sediaan formula optimum stick balm minyak atsiri daun sereh memiliki warna kuning cerah, bau khas daun sereh, konsistensi semi padat, bahan tercampur secara homogen, nilai $\mathrm{pH}$ sebesar 5,63 $\pm 0,06$, titik leleh pada suhu $44,5 \pm 0,5^{\circ} \mathrm{C}$, dan nilai daya lekat pada $2,437 \pm 0,106$ detik. Sifat fisik pada sediaan optimum stick balm minyak atsiri daun sereh telah memenuhi syarat sediaan stick balm.

\section{DAFTAR PUSTAKA}

Anief, M. 2013. Ilmu Meracik Obat: Teori dan Praktik Edisi ke-16. Yogyakarta: Gadjah Mada University Press.

Anjari, W., Taurina, W., \& Purwanti, N. U. 2015. Pengaruh Cera Alba Terhadap Sifat Fisik Lip Gloss Ekstrak Etanol Biji Kesumba Keling (Bixa orellana L.). Jurnal Mahasiswa Farmasi Fakultas Kedokteran UNTAN, 3(1): 1 - 13.

Arisanti, C. I. S., Indraswari, P. I. I., \& Budiputra, D. K. 2016. Pengaruh komposisi span ( 80 dan cera alba terhadap stabilitas fisik sediaan cold cream ekstrak etanol $96 \%$ kulit buah manggis (Garcinia mangostana L). Skripsi, Universitas Udayana, Bali.

Astuti, I. Y., Hartanti, D., \& Aminiati, A. 2010. Peningkatan Aktivitas Antijamur Candida albicans Salep Minyak Atsiri Daun Sirih (Piper bettle Linn.) melalui Pembentukan Kompleks Inklusi dengan B-Siklodekstrin. Traditional Medicine Journal, 15(3): 94-99.

Athaillah, \& Lianda, S. O. 2021. Formulasi dan Evaluasi Sediaan Balsem Stik dari Oleoresin Jahe Merah (Zingiber officinale rosc) Sebagai Pereda Nyeri Otot dan Sendi. Journal of Pharmaceutical And Sciences, 4(1): 34-40.

Azkiya, Z., Ariyani, H., \& Nugraha, T. 2017. Evaluasi Sifat Fisik Krim Ekstrak Jahe Merah (Zingiber officinale Rosc. var. rubrum) sebagai Antinyeri. Journal of Current Pharmaceutica Sciences, 1(1): 12-18.

Blanco, M. M., Costa, C. A. R. A., Freire, A. O., Santos, J. G., \& Costa, M. (2009). Neurobehavioral Effect of Essential Oil of Cymbopogon citratus in mice. Phytomedicine, 16(2-3): 265270. https://doi.org/10.1016/j.phymed.2007.04.007

Butler, H. 2000. Pouchers Perfumes, Cosmetics, and Soaps (10th ed.). New York: Kluwer Academic Publisher.

Fitriana, A. Y., Wahyuningrum, R., \& Sudarso. 2012. Daya Repelan dan Uji Iritasi Formula Lotion Ekstrak Etanol Daun Sirih (Piper bettle Linn.) dengan Variasi Basis Lanolin Terhadap Nyamuk Aedes aegypti. Pharmacy, 9(2): 1-9.

Gaware, V. M., Nagare, R., Dhamak, K. B., Khadse, A. N., Kotade, K. B., Kashid, V. A., \& Laware, R. B. 2013. Aromatherapy: Art or Science. International Journal of Biomedical Research, 4(2): 10. https://doi.org/10.7439/ijbr

Gumbara, Y. T., Murrukmihadi, M., \& Mulyani, S. 2015. Optimasi Formula Sediaan Lipstik Ekstrak Etanolik Umbi Ubi Jalar Ungu (Ipomoea batatas L.) dengan Kombinasi Basis Carnauba Wax dan Paraffin Wax Menggunakan Metode SLD (Simplex Lattice Design). Majalah Farmaseutik, 11(3): 336-345.

Irianto, I. D. K., Purwanto, P., \& Mardan, M. T. 2020. Aktivitas Antibakteri dan Uji Sifat Fisik Sediaan Gel Dekokta Sirih Hijau (Piper bettle L.) Sebagai Alternatif Pengobatan Mastitis Sapi. Majalah Farmaseutik, 16(2): 202 - 210. https://doi.org/10.22146/farmaseutik.v16i2.53793

Ittiqo, D. H., \& Wahid, A. R. 2019. Optimasi Formula Gel Serbuk Getah Ashitaba (Angelica keiskei Koidzumi) dan Uji Aktivitas Terhadap Lama Penyembuhan Luka Eksisi pada Kelinci. Pharmauho: Jurnal Farmasi, Sains, Dan Kesehatan, 4(2): 14 - 21. https://doi.org/10.33772/pharmauho.v4i2.6258

Kementerian Kesehatan RI. 2018. Hasil Utama Riset Kesehatan Dasar 2018. Jakarta: Kementrian Kesehatan RI.

Maysarah, H., Sari, I., Faradilla, M., \& Elfia Rosa, E. 2020. Stick Perfume Formulation from Jeumpa Flowers (Magnolia champaca (L) Baill Ex. Pierre). Proceedings of the 2nd International Conference of Essential Oils (ICEO 2019), L, 47-53. https://doi.org/10.5220/0009956100470053

Naibaho, O. H., Yamlean, P. V. Y., \& Wiyono, W. 2013. Pengaruh Basis Salep Terhadap Formulasi Sediaan Salep Ekstrak Daun Kemangi (Ocimum sanctum L.) Pada Kulit Punggung Kelinci yang Dibuat Infeksi Staphylococcus aureus. Jurnal Ilmiah Farmasi-UNSRAT, 2(02): 27-34.

Novita, R., Munira, M., \& Hayati, R. 2017. Formulasi Sediaan Salep Ekstrak Etanol Pliek U Sebagai Antibakteri. AcTion: Aceh Nutrition Journal, 2(2): 103-108 https://doi.org/10.30867/action.v2i2.62

Paramita, A. 2008. Optimasi formula span 80 dan tween 80 dalam cold cream obat luka ekstrak daun binahong (Anredera cordifolia (Ten.) Steenis.) dengan metode simplex lattice design. Skripsi, Universitas Sanata Dharma, Yogyakarta.

Purba, O. H., Tumanggor, N. T., Syafitri, A., \& Simorangkir, D. M. 2020. Pembuatan Sediaan Balsem Stick dari Sereh (Cymbopogon citratus (DC.) Stapf). Jurnal Penelitian Farmasi \& Herbal, 3(1): 75-81.

Rachmawati, D., Stevani, H., \& Santi, E. 2018. Uji Stabilitas Mutu Fisik Sediaan Masker Gel Wajah dari Ekstrak Daun Belimbing Wuluh (Averrhoa bilimbi L.) dengan Variasi Konsentrasi Carbopol. Media Farmasi, 14(1): 85-92. https://doi.org/10.32382/mf.v14i1.75 
Jurnal Penelitian Farmasi Indonesia 10(2), Desember 2021 ISSN : 2302-187X

$$
\text { e-ISSN 2656-3614 }
$$

Rohmani, S., \& Kuncoro, M. A. A. 2019. Uji Stabilitas dan Aktivitas Gel Handsanitizer Ekstrak Daun Kemangi. JPSCR : Journal of Pharmaceutical Science and Clinical Research, 4(1): 16-28. https://doi.org/10.20961/jpscr.v4i1.27212

Rowe, R. C., Sheskey, P. J., \& Owen, S. C. 2006. Handbook of Pharmaceutical Excipients Fifth Edition. New York: Royal Pharmaceutical Society of Great Britain.

Sandi, D. A. D., \& Musfirah, Y. 2018. Pengaruh Basis Salep Hidrokarbon dan Basis Salep Serap terhadap Formulasi Salep Sarang Burung Walet Putih. Jurnal Ilmiah Manuntung, 4(2): 149-155.

Sisco Research Laboratories Ltd., P. (2021a). Bees Wax pure. https://srlchem.com/products/product details/productId/1430 14/Bees-Wax-pure-8012-89-3, diakses 19 Oktober 2021.

Sisco Research Laboratories Ltd., P. (2021b). Lanolin Anhydrous Extrapure.

https://www.srlchem.com/products/product_details/productId /142516/Lanolin-anhydrous-extrapure-8006-54-0, Diakses 19 Oktober 2021.

Sulaswatty, A., Rusli, M. S., Abimanyu, H., \& Tursiloadi, S. 2019. Minyak Serai Wangi dan Produk Turunannya. In Lembaga Ilmu Pengetahuan Indonesia (LIPI), 9(2).
Tse, J. L. M., Flin, R. \& Mearns, K. 2007. Facets of Job Effort in Bus Driver Health: Deconstructing "Effort" in the Effort-Reward Imbalance Model. Journal of Occupational Health Psychology, 12(1): 48-62. https://doi.org/10.1037/10768998.12.1.48

Tucker, J. S., Sinclair, R. R., Mohr, C. D., Adler, A. B., Thomas, J. L., \& Salvi, A. D. 2008. A Temporal Investigation of the Direct, Interactive, and Reverse Relations Between Demand and Control and Affective Strain. Work and Stress, 22(2): 81-95. https://doi.org/10.1080/02678370802190383

Warnida, H., Putri, D. S., \& Sukawaty, Y. 2016. Formula Lipstik dengan Pewarna Alami dari Ekstrak Kelopak Bunga Rosella (Hibiscus sabdariffa L.). Jurnal Ilmu Farmasi Terapan dan Kesehatan, 1(1): 8-14.

Yanhendri, S. W. Y. 2012. Berbagai Bentuk Sediaan Topikal dalam Dermatogical. Cermin Dunia Kedokteran-194, 39(6): 423 430 .

Zaituni, Z., Khathir, R., \& Agustina, R. 2016. Penyulingan Minyak Atsiri Sereh Dapur (Cymbopogon citratus) dengan Metode Penyulingan Air-Uap. Jurnal Ilmiah Mahasiswa Pertanian, 1(1): 1009-1016. https://doi.org/10.17969/jimfp.v1i1.1085 